\title{
ANALISIS PEMEROLEHAN FONOLOGI ANAK USIA 3 TAHUN PADA MASYARAKAT BILINGUAL
}

\author{
Shabrina Salsabila1 ${ }^{1}$ Muhammad Rizkita ${ }^{2}$ \\ ${ }^{1}$ Fakultas Ilmu Tarbiyah dan Keguruan, UIN Sunan Kalijaga Yogyakarta, Jl. Laksda Adi Sucipto, \\ Papringan, Caturtunggal, Depok, Sleman, Daerah Istimewa Yogyakarta, \\ shabrinasalsabila44@gmail.com \\ ${ }^{2}$ Fakultas Ushuluddin dan Pemikiran Islam, UIN Sunan Kalijaga Yogyakarta, Jl. Laksda Adi Sucipto, \\ Papringan, Caturtunggal, Depok, Sleman, Daerah Istimewa Yogyakarta, \\ muhammadrizkita25@gmail.com
}

\begin{abstract}
The acquiring a child's first language (first language acquisition) is a natural process carried out by a child unconsciously to master the mother tongue (Dardjowidjojo in Kepirianto, 2012) So this implies that the environment affects word acquisition in children, especially in the environment in which they live. Moreover, Indonesia is a country that has a wealth of languages in which language is a symbol of a certain ethnicity (RD Kartikasari, 2019) This is what causes people to have two to three different everyday languages. The purpose of this study was to explore how the acquisition of phonology and vocabulary in children aged 3 years in this bilingual society. The research method used in this research is descriptive method with a qualitative approach. From the data obtained, it can be concluded that the environment affects a child's language acquisition. Children will imitate and absorb the vocabulary that is often spoken by the community. Children aged 3 years are sufficiently able to convey multiple sentences and their vocabulary is diverse although there are still some inaccurate phonemes such as / $\mathrm{c} /$ which should be / $\mathrm{/,} \mathrm{/} \mathrm{l/which} \mathrm{should} \mathrm{be} \mathrm{/} \mathrm{r} /$ and there are also some phonemes that are missing in a words like [men] which should be [candy]. Javanese vocabulary such as [ngono] [ben] [nggeh] is a loan word that the child gets through his surroundings.
\end{abstract}

Keywords: Phonology, language, bilingual community

\begin{abstract}
ABSTRAK
Pemerolehan bahasa pertama seorang anak (first language acquisition) merupakan proses alamiah yang dilakukan seorang anak secara tidak sadar untuk menguasai bahasa ibu (Dardjowidjojo dalam Kepirianto, 2012) Sehingga hal ini menyiratkan bahwa lingkungan mempengaruhi pemerolehan kata pada anak, terutama pada lingkungan tempat tinggal. Apalagi, Indonesia merupakan negara yang memiliki kekayaan bahasa yang mana bahasa sebagai simbol suatu etnis tertentu (RD Kartikasari, 2019) Hal inilah yang menyebabkan masyarakat memiliki dua hingga tiga bahasa keseharian yang berbeda. Tujuan penelitian ini dilakukan untuk mengeksplorasi bagaimana pemerolehan fonologi dan pembendaharaan kata pada anak usia 3 tahun di lingkungan masyarakat bilingual tersebut. Metode penelitian yang digunakan dalam penelitian ini adalah metode deskriptif dengan pendekatan kualitatif. Dari hasil data yang diperoleh dapat disimpulkan bahwa lingkungan mempengaruhi pemerolehan bahasa seorang anak. Anak akan meniru dan menyerap kosa kata yang kerap diucapkan oleh masyarakat. Anak usia 3 tahun sudah cukup mampu menyampaikan kalimat berganda dan kosa katanya pun beragam meskipun masih terdapat beberapa fonem yang belum tepat seperti /c/ yang seharusnya /s/, /l/ yang seharusnya /r/ dan terdapat pula beberapa fonem yang hilang dalam sebuah kata seperti [men] yang seharusnya [permen]. Kosa kata bahasa Jawa seperti [ngono] [ben] [nggeh] merupakan kata serapan yang diperoleh sang anak melalui lingkungan sekitarnya.
\end{abstract}

Kata Kunci : Fonologi, bahasa, masyarakat bilingual

Program Studi Pendidikan Bahasa dan Sastra Indonesia 


\section{DOI: https://doi.org/10.31943/bi.v6i1.77}

How to Cite :

Shabrina Salsabila, \& Muhammad Rizkita. (2021). ANALISIS PEMEROLEHAN FONOLOGI ANAK USIA 3 TAHUN DALAM MASYARAKAT BILINGUAL. Bahtera Indonesia; Jurnal Penelitian Bahasa Dan Sastra Indonesia , 6(1), 1-8. https://doi.org/10.31943/bi.v6i1.77

\section{PENDAHULUAN}

Bahasa merupakan alat komunikasi yang digunakan manusia untuk saling berkomunikasi satu sama lain. Suatu sistem yang digunakan dalam berkomunikasi dan beradaptasi dengan lingkungannya untuk bertukaran gagasan, pikiran, dan emosi disebut dengan bahasa (Strongman, 2017). Masa anak usia dini adalah masa keemasan dalam hidup manusia. Pada periode ini, otak mengalami perkembangan pesat. (Santrock, 2011) Anak usia 3 tahun sudah mampu mempraktikan ungkapan kata ganda (multiple-word utterances) atau dikenal juga sebagai ungkapan telegrafis (Dian Syahfitri, 2015) Bahasa apapun sangat rumit, tetapi sungguh menakjubkan bagaimana caranya anakanak di usia yang sangat muda (0-5 tahun) dapat memperoleh atau menguasainya mereka sendiri. Anak-anak selama Periode Linguistik mereka (1-5 tahun) secara tidak sadar berbicara kalimat yang rumit yaitu kalimat-kalimat yang berhubungan, bertanya, pertanyaan, menggunakan kata ganti yang tepat, meniadakan kalimat, membentuk relatif klausa, dan infleksi kata kerja dan kata benda (Fromkin, Rodman, dan Hyams, 2010) Senada dengan itu Fromkin (1983) juga menyatakan proses dari memperoleh bahasa pada usia sebelum 5 tahun disebut sebagai Zaman Keemasan. Periode ini menunjukkan kemajuan perkembangan bahasa dari satu tahap ke tahap lainnya.

Faktor yang mampu mempengaruhi pemerolehan bahasa seorang anak antara lain: 1) orang tua, 2) lingkungan, 3) teman sebaya, 4) kegiatan komunikasi (Nur Syamsiyah, 2017) Salah satu faktor utama yang mampu mempengaruhi pemerolehan bahasa anak selain orang tua adalah lingkungannya. Indonesia memiliki kekayaan bahasa yang banyak yang terdiri dari berbagai daerah yang berbeda. Bahasa Indonesia berfungsi sebagai lingua franca yaitu sistem sebagai penghubung komunikasi antara bahasa yang berbeda-beda. (Arif Izzak, 2009) Masyarakat Indonesia ratarata mampu menguasai lebih dari dua hingga tiga bahasa yang berbeda. Maka dari itu tidak heran apabila anak-anak mampu menggunakan dua hingga tiga bahasa yang berbeda karena pengalaman pemerolehan bahasa yang dialami sang anak pada lingkungan sekitarnya (Ahmad Wahyudin, 2012) Hubungan antara kemampuan anak dan lingkungan sekitar berkaitan erat hubungannya dalam memberi kontribusi kemampuan berbahasa (Enjang Burhanudin Yusuf, 2016) Belajar bahasa merupakan proses pembentukan dari kebiasaan (Meilan Arsanti, 2014) Struktur bahasa muncul akibat interaksi sosial yang terus menerus antara fungsi kognitif 
dan lingkungannya sehingga mempengaruhi anak untuk menirukan bahasa yang ada di sekitarnya (Haswinda Harpriyanti, 2018)

Perkembangan bahasa sangat erat kaitannya dengan aspek sosial si anak. Dunia sekitarnya membentuk kemampuannya dalam berbahasa. Para ahli misalnya Eva Clark menyebutkan bahwa penyerapan bahasa pertama terjadi di masa kanak-kanak mengikuti bahasa orang-orang di sekelilingnya. Ia menyebutkan dalam tulisannya berjudul "How Language Acquistion Builds on Cognitive Development" bahwa,

When children acquire a first language, they build on what they know conceptual information that discriminates and helps create categories for the objects, relations and events they experience. This provides the starting point for language from the age of 12 months on. So children first set up conceptual representations, then add linguistic representations for talking about experience. Do they then discard earlier conceptual representations in favour of linguistic ones, or do they retain them? Recent research on the coping strategies that young children (and adults) rely on when they are unable to draw on language suggest that they retainretain both types of representations for use as needed.

Pada usia kanak-kanak penguasaan bahasa murni berorientasi pada fungsi praktis sebagai alat komunikasi ketimbang bentuk bahasa. Anak-anak memiliki ciri-ciri pemerolehan bahasa yang berkesinambungan dari satu kata sederhana hingga gabungan kata dan kalimat yang lebih (Manurung, 2014) Perkembangan bahasa, seperti yang telah saya paparkan di atas mempunyai kaitan erat dengan lingkungan sekitarnya - bahkan dalam diktum lain - kemahiran bahasa diasosiasikan dengan kemampuan menyampaikan maksud pembicara kepada lawan bicara secara baik. Setiap kata merujuk pada dua hal mendasar.Pertama, kemampuan mempertemukan antara fenomena yang diwakili oleh suatu kata tertentu dengan objek rill-nya. Kedua, kemampuan mempertemukan satu kata dengan kata yang lain. (Mahabbati, 2013)

Fonologi berkaitan erat dengan pengorganisasian penggunaan suara dalam suatu sistem bahasa (Sloat, Taylor \& Hoard, 1978) Sedangkan fonem sendiri berarti satuan terkecil dari komponen suara yang membangun bahasa (Kent, 1993) Seorang anak bisa dianggap telah menguasai kata pertamanya jika mereka mampu mengucapkan kata-kata yang telah diketahui secara luas dan dapat mengasosiasikan kata-kata yang diujarkan dengan objek atau kejadian di lingkungannya (Dardjowidjojo, 2000). Bentuk kata tidak sempurna seperti 'pah' untuk 'papah', dan makna yang dimaksudkan mungkin tidak sesuai. Kosakata dasar seperti kata benda, kata kerja, kata sifat, kata bilangan, kata ganti, kata yang berhubungan dengan kekerabatan, dan kata depan, kosakata turunan (imbuhan prefiks, imbuhan sufiks, imbuhan infiks, dan imbuhan konfiks), dan kosakata ulang merupakan jenis kosakata yang telah diperoleh oleh anak usia 36 (Nurjamiaty, 2015). Sementara kalimat 
deklaratif/berita, kalimat imperatif/perintah, kalimat interogatif/tanya, dan kadang-kadang kalimat eksklamatif/seru telah mampu dikuasai oleh anak usia 3;0-4;0 (Yuniarsih, 2013).

Pada tulisan ini, peneliti akan mencoba memperlihatkan gambaran pemerolehan bahasa subjek penelitian yakni seorang anak yakni Uwais yang berumur tiga tahun. Aspek yang

\section{METODE PENELITIAN}

Metode penelitian yang digunakan dalam penelitian ini adalah metode deskriptif dengan pendekatan kualitatif. Peneliti melakukan pengumpulan data dengan menjadi lawan ujar subjek penelitian, Uwais berumur tiga tahun enam bulan. Metode deskriptif dipilih oleh peneliti karena metode ini dapat memberikan gambaran representatif mengenai bahasa dan latar ujarnya.

Mengamati anak secara langsung yang menjadi subjek penelitian merupakan cara yang dilakukan peneliti untuk memperoleh sampel. Teknik yang digunakan adalah teknik simak libat cakap yaitu menyimak kata-kata yang bisa diucapkan oleh anak. Selain itu, peneliti juga memperhatikan percakapan Uwais dengan orang tuanya. Berinteraksi dan mendorong subjek penelitian untuk mengucapkan kata-kata juga dilakukan oleh peneliti. Data dikumpulkan dari pengamatan dan hasil pemahaman kata yang diucapkan oleh sang anak kemudian dicatat. Penelitian ini dilakukan selama tiga hari. Tahap analisis data dalam penelitian ini terdiri atas tiga tahap, yaitu sebagai berikut. Pertama, diamati berada dalam tataran fonologis, khususnya pada cabang fonemik. Uwais tinggal di lingkungan keluarga yang terbiasa menggunakan bahasa Jawa, sehingga pada tulisan ini, peneliti juga sedapatnya menangkap kosakata atau istilah dalam bahasa Jawa yang diucapkan.

reduksi; ada empat cara yang dilakukan dalam reduksi, yaitu (1) Melakukan transkripsi data tuturan yang kemudian menjadi bentuk tulisan; (2) Data yang telah ditranskripsikan akan diidentifikasi (3) Melalui proses pengklasifikasian terlebih dahulu (4) Melakukan pemaknaan terhadap data yang sebelumnya sudah diklasifikasikan. Kedua, tahap penyajian; pada tahap ini, data yang telah diklasifikasikan disajikan dalam bentuk tabel. Ketiga, tahap penarikan kesimpulan yaitu proses verifikasi ulang (Miles dan Huberman, 2014).

\section{HASIL DAN PEMBAHASAN}

\section{Pemerolehan dalam Tataran Fonologi}

Fonologi merupakan salah satu bidang dalam ilmu bahasa yang membahas tentang bunyi secara umum. Terdapat dua cabang fonologi yaitu fonetik dan fonemik. Fonetik merupakan cabang studi fonologi yang mengkaji bunyi tanpa memperhatikan apakah bunyi tersebut memiliki fungsi sebagai pembeda makna kata atau tidak, sementara jika bunyi bahasa yang berfungsi membedakan makna kata disebut dengan fonemik (Abdul Chaer, Linguistik umum, (Jakarta: rineka cipta, 2003).

Fakultas Keguruan dan Ilmu Pendidikan 
Dalam analisis fonologi, data yang dipaparkan oleh peneliti berbentuk fonetis dan teks. Selanjutnya untuk memperlihatkan ujaran yang diucapkan oleh subjek penelitian ini data dibentuk ke dalam tulisan.

\section{Transkip Pertama}

[Aku Ais] [aku ceorang capiten] [mempunyai edang anjang] [ciapa ndak turun][diajalin bu gulu] [toko mucik][mucik opo] [mau mam naci tok] [ini apa cih] [ibu mau cilup] [belicik cih] [jangan belantem]

\section{Pengucapan yang seharusnya}

Aku Uwais. Aku seorang kapiten. Mempunyai pedang panjang. Siapa hendak turun. Diajarin bu guru. Toko musik. Musik apa. Mau makan nasi saja. Ini apa sih. Ibu mau sirup. Berisik sih. Jangan berantem.

\section{Analisis Fonologis}

Kalimat yang diucapkan oleh Uwais terdapat perubahan kata dan bunyi bahasa seperti [ais] yang seharusnya uwais. [ceorang] yang seharusnya seorang, fonem /s/ berubah menjadi/c/, terjadi pula pada kata [ciapa] [mucik] [naci] [cih] [cilup] [belicik] dan kata [belantem] yang seharusnya berantem, fonem /r/ berubah menjadi /l/, begitu pula pada kata [bu gulu]

Selain itu, pemerolehan kata asing selain bahasa Indonesia seperti kata [opo] dan [tok] yang menyerap dari bahasa Jawa. Hal ini dikarenakan Uwais berada pada lingkup masyarakat bilingual yang bahasa kesehariannya berbahasa Indonesia dan bahasa
Jawa. Secara utuh seperti yang tersaji pada beberapa percakapan berikut.

\section{Transkip Kedua}

\section{Peristiwa tutur 2 (Menanyakan makanan)}

$\mathbf{P}:$ Itu apa dek?

$\mathbf{U}$ : Taho. Kak mau ndak taho?

P : Nggak

$\mathbf{U}$ : Ais cuka taho

P: Kakak sukanya telur

$\mathbf{U}$ : Ais cuka telul kok!

P: Telur apa?

U: Telul itu lho..goleng

\section{Analisis Fonologis}

Dari hasil percakapan tersebut dapat diketahui bahwa Uwais sudah mampu mengucapkan kata [tahu] hanya saja terdapat huruf yang berubah pengucapannya seperti fonem /u/ menjadi /o/. Kata [cuka] yang seharusnya [suka] terdapat fonem /s/ yang berubah menjadi /c/, kata [telul] yang seharusnya [telur], kata [goleng] yang seharusnya [goreng] terdapat fonem /r/ yang berubah menjadi /l/

\section{Transkip Ketiga}

\section{Peristiwa tutur 3 (menanyakan alasan)}

U: Sayur...Sayur

P: Kok sayur? Sahur dek

U: Sayur...Sayur kok

P: Uwais sahur gak tadi?

U: Ndak kok

P: Kenapa?

U: Ais kan macih kecil

P: Udah besar uwais itu

U: Macih kecil! Ihhh... 


\section{Analisis Fonologis}

Seorang anak akan mudah merekam kalimat yang sering diucapkan di dalam lingkungannya meskipun seorang anak belum mengerti bagaimana cara mengucapkan kalimat tertentu dengan benar. Seperti pada kata [sahur] yang berubah menjadi kata [sayur] terdapat fonem /h/ yang berubah menjadi /y/ kata [macih] yang seharusnya [masih] terdapat fonem /s/ yang berubah menjadi /c/

\section{Transkip data 4}

Peristiwa tutur 4 (menanyakan mainan baru)

P: Kakak mau beli mainan baru, Uwais nggak?

$\mathbf{U}$ : Ais beli ainan kok. Beli pecawat

P: Kapan?

U: Kapan cih. Ais punya layangan. Buanyak.

P: Berapa layangannya?

U: Dua

P: Uwais bisa main layangan?

U: Bica toh. Kakak ndak bica mainnya

P: Main sama siapa?

U: Sama ayah

P: Dimana?

U: Citu lho, di atas lho yang...yang banyak poonnya

\section{Analisis Fonologis}

Kalimat yang diucapkan oleh Uwais terdapat penghilangan huruf seperti [ainan] yang seharusnya mainan, kata [poon] yang seharusnya [pohon], begitu pula dengan kata [pecawat] yang seharusnya [pesawat], kata [cih] yang seharusnya [sih], kata [bica] yang seharusnya [bisa], kata [citu] yang seharusnya [situ] terdapat fonem /s/ yang berubah menjadi
/c/.Kata [buanyak] yang terserap dari lingkungannya berbeda dari kata baku bahasa Indonesia yang sebenarnya yaitu [banyak]

\section{Transkip data 5}

\section{Peristiwa tutur 5 (menawarkan teh)}

P: Uwais mau teh nggak?

$\mathbf{U}:$ Ndak mau

P : Beneran gak mau?

$\mathbf{U}$ : Uwais maunya men kok

P: Nanti sakit lho giginya

$\mathbf{U}$ : Ais lajin cikat gigi

P: Mau sirup gak?

U: Ibuu...Ais mau cilup

\section{Analisis Fonologis}

Kalimat yang diucapkan oleh Uwais terdapat penghilangan beberapa huruf seperti kata [men] yang seharusnya [permen]. Kata [lajin] yang seharusnya [rajin] terdapat fonem $/ \mathrm{r}$ / yang berubah menjadi /1/, kata [cikat] yang seharusnya [sikat] terdapat fonem /s/ yang berubah menjadi /c/ begitu pula dengan kata [cilup] yang seharusnya [sirup]

\section{Transkip data 6}

\section{Peristiwa tutur 6 (Meminta ingin dibelikan mainan)}

U: Ais mau beli mainan lho

P: Mainan apa? Kan udah beli mainan

$\mathbf{U}$ : Yang mobil trek yang gede lho. Lha ais meh jejerke ngono lho ben panjang lho

P: Ohh...biar panjang?

U: Ho'oh tho nek dijejerke panjang lho

P: Nanti beli ya, nggeh mboten?

U: Nggeh

\section{Analisis Fonologis}

Fakultas Keguruan dan Ilmu Pendidikan 
Dari percakapan di atas dapat diketahui bahwa Uwais mengambil kosa kata bahasa Jawa seperti kata [gede] [meh] [jejerke] [ngono] [ben] [nek] [ho'oh] [nggeh] kata-kata tersebut diserap

\section{SIMPULAN}

Masyarakat Indonesia dikenal sebagai masyarakat bilingual atau tringual yang mana dari hal tersebut dapat diartikan bahwa masyarakat Indoenesia mampu berbicara lebih dari satu bahasa. Salah satu faktor yang mempengaruhi pemerolehan bahasa anak adalah lingkungan sekitar. Dari lingkungannya inilah sang anak akan meniru dan menyerap kosa kata yang kerap diucapkan oleh masyarakat. Anak usia 3 tahun sudah cukup mampu menyampaikan kalimat berganda dan kosa katanya pun beragam meskipun masih terdapat

\section{DAFTAR PUSTAKA}

Arsanti, M. (2014). Pemerolehan Bahasa Pada Anak (Kajian Psikolinguistik). PBSI, 3(2), 24-44.

Clark, E. V. (2004). How Language Acquisition Builds In Cognitive Development. Trends: In Cognitive Science, 8(10), 472-478

Dardjowidjojo. (2000). Echa: kisah pemerolehan bahasa anak Indonesia. Jakarta: Grasindo.

Dwi Yuniarsih, D. (2013). Pemerolehan Kalimat Bahasa Indonesia Pada Anak Usia 3;04;0 Tahun (Studi Kasus Pada Muhammad Ahsan Hafiz). Jurnal Pendidikan Bahasa dan Sastra Indonesia, 1(2), 477-484.

Fromkin, V. (1983). An Introductionto Language (3rd ed.). New York: CBS College Publishing. karena lingkungan tempat tinggal Uwais yang berada pada lingkungan masyarakat bilingual yaitu bahasa kesehariannya menggunakan bahasa Indonesia dan bahasa Jawa.

beberapa fonem yang belum tepat seperti /c/ yang seharusnya /s/, /1/ yang seharusnya /r/ dan terdapat pula beberapa fonem yang hilang dalam sebuah kata seperti [men] yang seharusnya [permen]. Kosa kata bahasa Jawa seperti [ngono] [ben] [nggeh] merupakan kata serapan yang diperoleh sang anak melalui lingkungan sekitarnya. Perpaduan antara kemampuan kognitid dan pengalaman pemerolehan bahasa dalam masyarakat bilingual menjadikan seorang anak yang berada pada masa emas menjadi anak yang berkemampuan bilingual.

Harpriyanti, H. (2018). Pemerolehan Fonologi Anak Usia 3 Tahun (Fatia Hasuna). Prosiding Seminar Nasional Linguistik VI, 161-167. Banjarmasin: STKIP PGRI Banjarmasin.

Izzak, A. (2009). Bilingualisme dalam Perspektif Pengembangan Bahasa Indonesia. Mabasan, 3(1), 15-29.

Kartikasari, R. D. (2019). Penggunaan Bilingualisme Pada Masyarakat yang Berwirausaha. Jurnal Pendidikan Bahasa dan Sastra Indonesia, 2(1), 4754.

Kent, R. (1993). Normal Aspect of Articulation. New Jersey: Prentice-Hall.

Kepirianto. (2010). Pemerolehan Fonologi Anak Usia Tahun Pada Masyarakat Bilingual. Seminar Nasional Pemertahanan Bahasa Nusantara, 139.

Mahabbati, A. (2013). language and mind menurut Vygotsky, Aplikasi terhadap 
Pendidikan Anak dan Kritiknya. Jurnal Pendidikan Edukasia, 2(2), 1-14

Manurung, R. (2014). Pemerolehan bahasa pada anak usia 4-5 tahun dengan stimulasi games edukasi. Ranah, 3(1), 137-145 .

Miles, M. B. (2005). Qualitative Data Analysis (Terjemahan). Jakarta: UI Press.

Nurjamiaty. (2015). Pemerolehan Bahasa Anak Usia Tiga Tahun Berdasarkan Tontonan Kesukaannya Ditinjau Dari Konstruksi Semantik. Edukasi Kultura, 2(2), 42-60.

Santrock, J. W. (n.d.). REMAJA. (B. Widyasinta, Trans.) Jakarta: Erlangga.

Sloat, C. D. (1978). Introduction to Phonology. New Jersey: Prentice-Hall.

Strongman, L. (2017). Sosiolinguistics interdisciplinary Perpective. New York: Intech.

Suwandi, S. (2010). A Through Study On a Child Learning Her First Language: A case study on a three-year old child. Eternal, 1(2), 1-15.
Syahfitri, D. (2015). Pemerolehan Bahasa Pada Anak Usia Tiga Tahun. Medan Makna, 13(1), 87-94.

Syamsiyah, N. (2017). Pemerolehan Bahasa Pada Anak Usia 2-3 Tahun Sebagai Alternatif Untuk Mendongkrak Kecerdasan Bahasa Melalui Kegiatan Mendongeng. HARKAT, 13(1), 82-97.

Wahyudin, A. (2012). Bilingualisme: Konsep dan Pengaruhnya Terhadap Individu. Seminar Internasional PIBSI XXXIV. Purwokerto: Universitas Negeri Yogyakarta.

Yusuf, E. B. (2016). Perkembangan dan Pemerolehan Bahasa Anak. Yinyang: Jurnal Studi Islam dan Gender, 11(1), 40-60. 